\title{
Effects of propofol on the proliferation and migration of liver cancer cells
}

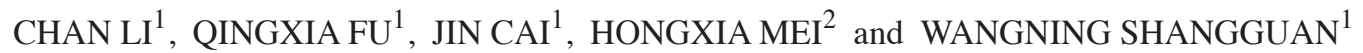 \\ ${ }^{1}$ Department of Anesthesiology and Perioperative Medicine; ${ }^{2}$ Key Laboratory of Anesthesiology of \\ Zhejiang Province, The Second Affiliated Hospital and Yuying Children's Hospital of \\ Wenzhou Medical University, Wenzhou, Zhejiang 325027, P.R. China
}

Received September 13, 2020; Accepted March 10, 2021

DOI: $10.3892 /$ etm.2021.10165

\begin{abstract}
Liver cancer is a malignant cancer with worldwide prevalence. It has been reported that cancer cells are usually exposed to a hypoxic microenvironment, which is associated with a poor prognosis in patients with cancer. Propofol is an intravenous anesthetic that is widely used in cancer surgery. The present study aimed to determine the effects of propofol stimulation on the viability, proliferation and migration of liver cancercells undernormoxia and cobaltchloride $\left(\mathrm{CoCl}_{2}\right)$-induced hypoxia. Under normoxia, HepG2 and HCCLM3 cells were randomly divided into six groups as follows: i) Control group; ii) $10 \mu \mathrm{M}$ propofol group; iii) $25 \mu \mathrm{M}$ propofol group; iv) $50 \mu \mathrm{M}$ propofol group; v) $100 \mu \mathrm{M}$ propofol group; and vi) DMSO group. Cell viability and proliferation were analyzed using Cell Counting Kit-8 (CCK-8) and 5-ethynyl-2'-deoxyuridine (EdU) assays, respectively, following 24 or $48 \mathrm{~h}$ of propofol treatment. In addition, wound healing and Transwell migration assays were used to determine the changes in cell migration. Under $\mathrm{CoCl}_{2}$-induced hypoxia, the protein levels of hypoxia inducible factor- $1 \alpha$ (HIF-1 $\alpha)$ of HepG2 cells were analyzed using western blotting. Subsequently, CCK-8 and wound healing assays were used to determine the effect of propofol on cell viability and migration. The results of the present study revealed that propofol stimulation had no significant effect on the viability, proliferation and migration of HepG2 and HCCLM3 cells under normoxia. The protein levels of HIF-1 $\alpha$ were significantly upregulated following the treatment with $200 \mu \mathrm{M} \mathrm{CoCl}_{2}$ for $12 \mathrm{~h}$. However, no significant differences were found in the viability and migration of HepG2 cells following the stimulation with propofol in the presence of $\mathrm{CoCl}_{2}$. In conclusion, the findings of the present study revealed
\end{abstract}

Correspondence to: Dr Wangning Shangguan, Department of Anesthesiology and Perioperative Medicine, The Second Affiliated Hospital and Yuying Children's Hospital of Wenzhou Medical University, 109 West Xueyuan Road, Wenzhou, Zhejiang 325027, P.R. China

E-mail: sgwning@163.com

Key words: propofol, liver cancer, viability, proliferation, migration that propofol exerted no effect on the viability, proliferation and migration of HepG2 and HCCLM3 cells under normoxic and hypoxic conditions.

\section{Introduction}

Liver cancer is the sixth most common type of cancer and the fourth leading cause of cancer-associated mortality worldwide, accounting for $\sim 841,000$ newly diagnosed cases and 782,000 deaths annually (1). Notably, China accounts for $\sim 1 / 2$ of all cases and deaths (2). In the United States, the morbidity and mortality of liver cancer is growing at a faster rate compared with any other type of cancer $(3,4)$. Surgical resection remains the first-choice treatment option for early-stage patients (5); however, a 5-year recurrence rate as high as $70 \%$ has been reported following liver cancer resection $(6,7)$, and there is currently no adjuvant therapy available for patients to prevent or reduce postoperative metastases and the formation of de novo tumors (8). Thus, the prognosis and survival outcomes of patients following curative liver cancer resection remain unsatisfactory. It has been reported that cellular and molecular events involved in tumor metastasis may be notably affected during or immediately following surgery (9). However, it has been suggested that during curative resection, the surgery-induced stress response and immunosuppression, in addition to the weakened immune function following surgery, may activate a series of events involved in the metastasis of tumors (10-12). In addition, operative manipulation itself has also been suggested to promote the dissemination of cancer cells (12). Therefore, the perioperative period has been suggested as a window of opportunity to effectively reduce cancer metastasis and recurrence.

Propofol is an anesthetic that has been widely used in the clinic. Recently, the non-anesthetic properties of propofol $(13,14)$, suchasitsimmunomodulatory,neuroprotective, antioxidant and anticancer effects, have been investigated in more detail. Previous studies in multiple cancer types, including liver (15,16), lung (17), breast (18), colorectal (19), gastric (20), prostate (21) and pancreatic cancer (22), have reported that propofol exerts direct anticancer effects by interfering with the biological functions of cancer cells through a variety of mechanisms to inhibit tumor proliferation, invasion and metastasis and promote apoptosis. In addition, propofol 
may also induce indirect effects by affecting the functions of immune cells (23). However, the studies investigating the role of propofol in cancer have reported conflicting results. For example, Zhang et al (24) reported that propofol exerts oncogenic activity by activating NF-E2-related factor 2 (Nrf2), which leads to an increase in the proliferation and invasion of gallbladder cancer cells. In another study by Ecimovic et al (25), the results revealed that propofol had no effect on the proliferation of breast cancer cells. Thus, the association between propofol and cancer progression requires further investigation.

Solid tumor cells usually exist within a hypoxic microenvironment, which is caused by the imbalance of oxygen supply and demand (26). Tumor cells in the hypoxic environment have been observed to undergo a series of adaptive changes, in which the activation of the hypoxia inducible factor- $1 \alpha$ (HIF-1 $\alpha$ ) pathway plays an important role. HIF-1 $\alpha$ is rapidly degraded under normoxia, but it can accumulate and be activated under hypoxic conditions (27). The cobalt ion in cobalt chloride $\left(\mathrm{CoCl}_{2}\right)$ can replace $\mathrm{Fe}^{2+}$ on the active site of prolyl hydroxylase (PHD), which is a key enzyme required for the degradation of HIF-1 $\alpha$ under normoxic conditions. This blocks the activity of PHD and stabilizes HIF-1 $\alpha$, which subsequently upregulates the protein levels of HIF- $1 \alpha$ and thereby induces its transcriptional activity (28). Therefore, $\mathrm{CoCl}_{2}$ was used as a chemical hypoxia simulant in the present study.

The present study aimed to determine the effects of propofol on the viability, proliferation and migration of HepG2 and HCCLM3 cells under normoxia and $\mathrm{CoCl}_{2}$-induced hypoxia in vitro.

\section{Materials and methods}

Cell culture and treatment. HCCLM3 and HepG2 cells (Kunming Cell Bank of Type Culture Collection) were cultured in DMEM (cat. no. C11995500BT; Gibco; Thermo Fisher Scientific, Inc.) supplemented with 10\% FBS (cat. no. 10099141; Gibco; Thermo Fisher Scientific, Inc.) and $1 \%$ penicillin-streptomycin (cat. no. P1400; Beijing Solarbio Science \& Technology, Co., Ltd.). Both cells were maintained in an incubator with $5 \% \mathrm{CO}_{2}$ at $37^{\circ} \mathrm{C}$, and routinely digested with $0.25 \%$ Trypsin-EDTA (cat. no. 25200072 ; Gibco; Thermo Fisher Scientific, Inc.) for subculture upon reaching 80-90\% confluence.

The plasma concentration of propofol required for sedation in the intensive care unit is $\sim 2 \mu \mathrm{g} / \mathrm{ml}(11.2 \mu \mathrm{M})$ (29) and 3-8 $\mu \mathrm{g} / \mathrm{ml}(16.8-44.8 \mu \mathrm{M})$ for general anesthesia (30). Therefore, the present study used a range of concentrations of propofol $(10,25,50$ and $100 \mu \mathrm{M})$. Under normoxia, HepG2 and HCCLM3 cells were randomly divided into six groups: i) Control group (untreated cells); ii) $10 \mu \mathrm{M}$ propofol (cat. no. Y0000016; Sigma-Aldrich; Merck KGaA) group; iii) $25 \mu \mathrm{M}$ propofol group; iv) $50 \mu \mathrm{M}$ propofol group; v) $100 \mu \mathrm{M}$ propofol group; and vi) DMSO (cat. no. D2650; Sigma-Aldrich; Merck KGaA) group. To simulate hypoxia, HepG2 cells were treated with $200 \mu \mathrm{M} \mathrm{CoCl}_{2}$ (cat. no. C8661; Sigma-Aldrich; Merck KGaA) or different concentrations of propofol $(10,25,50$ or $100 \mu \mathrm{M})$ in the presence of $200 \mu \mathrm{M}$ $\mathrm{CoCl}_{2}$ for $12 \mathrm{~h}$. Propofol was dissolved in DMSO, and the final concentration of DMSO in both the DMSO and propofol groups was $0.05 \%$.

Cell Counting Kit-8 (CCK-8) assay. The viability of HepG2 and HCCLM3 cells was analyzed using a CCK-8 assay (cat. no. CK04; Dojindo Molecular Laboratories, Inc.). Briefly, cells were seeded into 96-well plates at a density of $6 \times 10^{3}$ cells/well (for $24 \mathrm{~h}$ propofol stimulation) or $4 \times 10^{3}$ cells/well (for $48 \mathrm{~h}$ propofol stimulation). Under normoxia, the cells were treated with different concentrations of propofol or $0.05 \%$ DMSO for 24 or $48 \mathrm{~h}$. For hypoxia simulation, cells were exposed to propofol in the presence of $200 \mu \mathrm{M} \mathrm{CoCl}_{2}$ for $12 \mathrm{~h}$. Following the incubation, $10 \mu \mathrm{l}$ CCK-8 solution was added into each well and incubated for a further $1 \mathrm{~h}$. The absorbance of each well was measured at a wavelength of $450 \mathrm{~nm}$ using a microplate reader (Epoch2NS; BioTek Instruments, Inc.).

5-ethynyl-2'-deoxyuridine (EdU) assay. Cell proliferation was analyzed using a Click-iT ${ }^{\mathrm{TM}}$ EdU Imaging kit (cat. no. C10337; Invitrogen; Thermo Fisher Scientific, Inc.). Briefly, cells were cultured at a density of $5 \times 10^{4}$ cells/well (for $24 \mathrm{~h}$ propofol stimulation) or $3 \times 10^{4}$ cells/well (for $48 \mathrm{~h}$ propofol stimulation) in 24-well plates for $24 \mathrm{~h}$ and then treated with different concentrations of propofol or $0.05 \%$ DMSO for 24 or $48 \mathrm{~h}$. Following the incubation, the cells were labeled for $2 \mathrm{~h}$ with $10 \mu \mathrm{M}$ EdU solution and then fixed with $4 \%$ paraformaldehyde (Shanghai Lingfeng Chemical Reagent Co., Ltd.) for $15 \mathrm{~min}$ at room temperature. Cells were permeabilized with 0.5\% Triton X-100 (cat. no. 0694; Beijing Solarbio Science \& Technology Co., Ltd.) for $20 \mathrm{~min}$. EdU-incorporated cells and all cells were stained with Alexa Fluor fluorescent dye and Hoechst 33342 solution, respectively, for $30 \mathrm{~min}$ at room temperature, away from light. Subsequently, stained cells were visualized in five randomly selected fields of view using a fluorescence microscope (cat. no. DM5500B; Leica Microsystems $\mathrm{GmbH}$ ), and the percentage of EdU-positive cells was calculated. Analysis was performed using ImageJ version 1.8.0 software (National Institutes of Health).

Wound healing assay. A total of $1 \times 10^{6}$ cells were seeded into each well of six-well plates and cultured for $24 \mathrm{~h}$. Upon cells reaching $100 \%$ confluence, an artificial scratch was made in the middle of the cell monolayer using a 200- $\mu$ l pipette tip. The cell medium was subsequently removed and replaced with fresh DMEM containing $10,25,50$ or $100 \mu \mathrm{M}$ propofol or $0.05 \%$ DMSO under normoxia. Cells under hypoxia were treated with propofol combined with $200 \mu \mathrm{M} \mathrm{CoCl}_{2}$. The wound closure was observed and images were captured using an inverted microscope (TS100-F; Nikon Corporation) at 0 and $24 \mathrm{~h}$. Analysis was performed using ImageJ version 1.8.0 software.

Transwell migration assay. Analysis of cell migration was conducted using a 24-well Transwell chamber (pore size, 8- $\mu \mathrm{m}$; cat. no. 3422; Corning, Inc.). Serum-starved HCCLM3 cells $\left(5 \times 10^{4}\right.$ cells) suspended in $200 \mu 1$ serum-free DMEM containing $10,25,50$ or $100 \mu \mathrm{M}$ propofol or $0.05 \%$ DMSO were plated into the upper chamber. The lower chamber was filled with $600 \mu$ l complete medium supplemented with $20 \%$ FBS (cat. no. 10099141; Gibco; Thermo Fisher Scientific, 
A
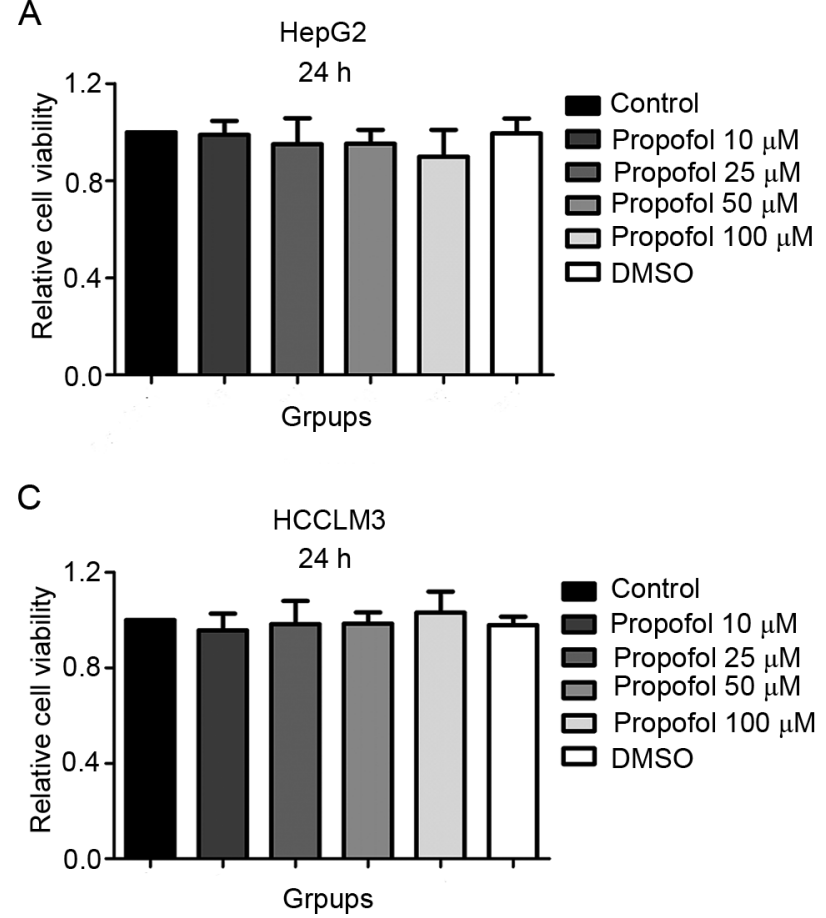

B

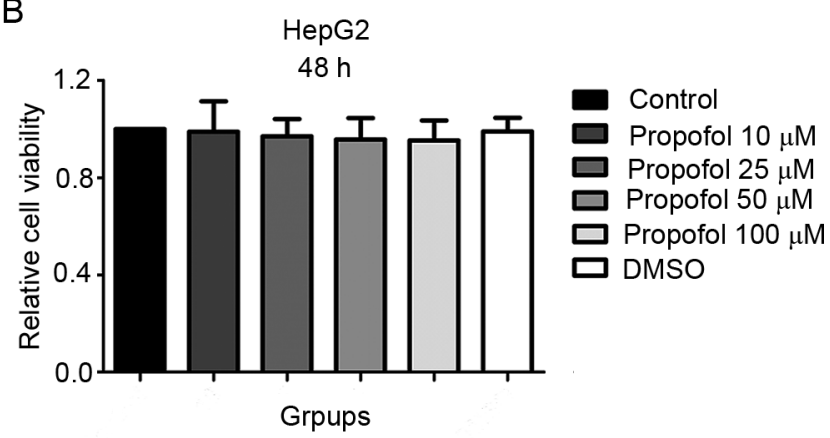

D

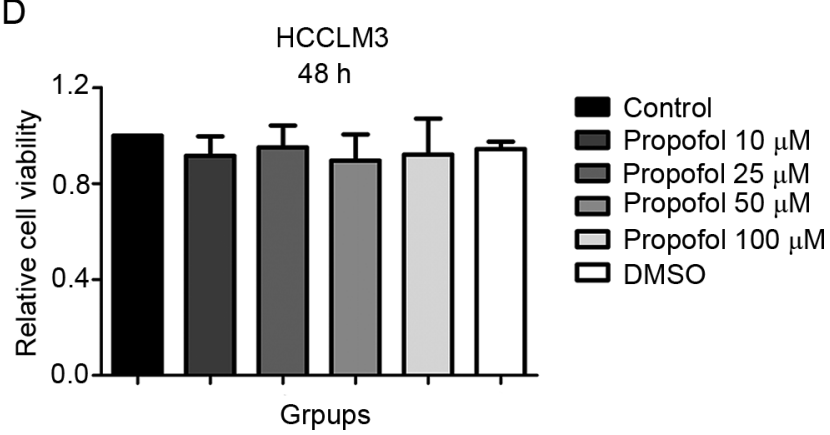

Figure 1. Effect of propofol on the viability of (A and B) HepG2 and (C and D) HCCLM3 cells under normoxia.

Inc.). Following $48 \mathrm{~h}$ of incubation at $37^{\circ} \mathrm{C}$, the migratory cells in the lower chamber were fixed with $4 \%$ paraformaldehyde for $30 \mathrm{~min}$ at room temperature and stained with crystal violet solution (cat. no. C0121; Beyotime Institute of Biotechnology) for $30 \mathrm{~min}$ at room temperature. The non-migratory cells remaining in the upper chamber were gently removed with a cotton swab. The number of migratory cells was counted in five randomly selected fields of view using an inverted microscope (TS100-F; Nikon Corporation) at a high magnification (x400). Analysis was performed using ImageJ version 1.8.0 software.

Western blotting. HepG2 cells treated with 100,200 or $300 \mu \mathrm{M}$ $\mathrm{CoCl}_{2}$ for 4, 8, 12 or $24 \mathrm{~h}$ were lysed on ice with RIPA lysis buffer (cat. no. P0013B; Beyotime Institute of Biotechnology) supplemented with $100 \mathrm{mM}$ phenylmethanesulfonyl fluoride (1\%; cat. no. ST506; Beyotime Institute of Biotechnology) and $1 \%$ protein phosphatase inhibitor (cat. no. P1260; Applygen Technologies, Inc.). The samples were centrifuged at $12,000 \mathrm{x} \mathrm{g}$ for $20 \mathrm{~min}$ in a centrifuge (cat. no. 5417R; Eppendorf) at $4^{\circ} \mathrm{C}$ and the supernatants were collected. The protein concentration was quantified using an enhanced BCA protein assay kit (cat. no. P0010; Beyotime Institute of Biotechnology), according to the manufacturer's protocol, and $30 \mu \mathrm{g}$ protein/lane was separated via 10\% SDS-PAGE. The separated proteins were subsequently transferred onto polyvinylidene fluoride membranes (cat. no. IPVH00010; EMD Millipore) and blocked with 10\% non-fat milk for $2 \mathrm{~h}$ at room temperature. The membranes were then incubated overnight with the following primary antibodies on a shaker at $4^{\circ} \mathrm{C}$ : Anti-HIF-1 $\alpha$ (rabbit; 1:1,000; cat. no. ab51608; Abcam) and anti- $\beta$-tubulin (rabbit; $1: 1,000$; cat. no. 10068-1-AP; ProteinTech Group, Inc.). Following the primary antibody incubation, the membranes were incubated with a horseradish peroxidase-conjugated goat anti-rabbit IgG secondary antibody (1:3,000; cat. no. SA00001-2; ProteinTech Group, Inc.) for $1 \mathrm{~h}$ at room temperature. Protein bands were visualized using enhanced chemiluminescence western blotting substrates (cat. no. K-12045-D20; Advansta, Inc.). Densitometric analysis was performed using ImageJ version 1.8.0 software.

Statistical analysis. Statistical analysis was performed using GraphPad Prism version 5.0 software (GraphPad Software,Inc.). Data of three of more experimental repeats are presented as the mean \pm SD. Data that were normally distributed and had an equal variance were analyzed using a one-way ANOVA, after which a Tukey's test was performed for multiple comparisons. Otherwise, Kruskal-Wallis test was used, followed by Dunn's multiple comparison test. $\mathrm{P}<0.05$ was considered to indicate a statistically significant difference.

\section{Results}

Propofol exerts no effect on the viability of HepG2 and HCCLM3 cells under normoxia. The results of the CCK-8 assay revealed that compared with the control $(1.00 \pm 0.00)$ and DMSO $(0.99 \pm 0.06)$ groups, the viability of HepG2 cells stimulated with $10(0.99 \pm 0.06), 25(0.95 \pm 0.11), 50(0.95 \pm 0.16)$ or $100 \mu \mathrm{M}(0.90 \pm 0.11)$ propofol for $24 \mathrm{~h}$ was not significantly different (Fig. 1A). Similar findings were observed in HepG2 cells following $48 \mathrm{~h}$ of propofol stimulation (control, $1.00 \pm 0.00$; DMSO, 0.99 $\pm 0.06 ; 10 \mu \mathrm{M}$ propofol, 0.99 $\pm 0.12 ; 25 \mu \mathrm{M}$ propofol, 0.97 $\pm 0.07 ; 50 \mu \mathrm{M}$ propofol, 0.96 $\pm 0.09 ; 100 \mu \mathrm{M}$ propofol, 0.95 \pm 0.08 ; Fig. 1B), in HCCLM3 cells following $24 \mathrm{~h}$ of propofol stimulation (control, 1.00 \pm 0.00 ; DMSO, $0.98 \pm 0.04 ; 10 \mu \mathrm{M}$ propofol, $0.96 \pm 0.07 ; 25 \mu \mathrm{M}$ propofol, $0.98 \pm 0.10 ; 50 \mu \mathrm{M}$ propofol, $0.98 \pm 0.05 ; 100 \mu \mathrm{M}$ propofol, $1.03 \pm 0.09$; Fig. 1C) and in HCCLM3 cells following $48 \mathrm{~h}$ of 


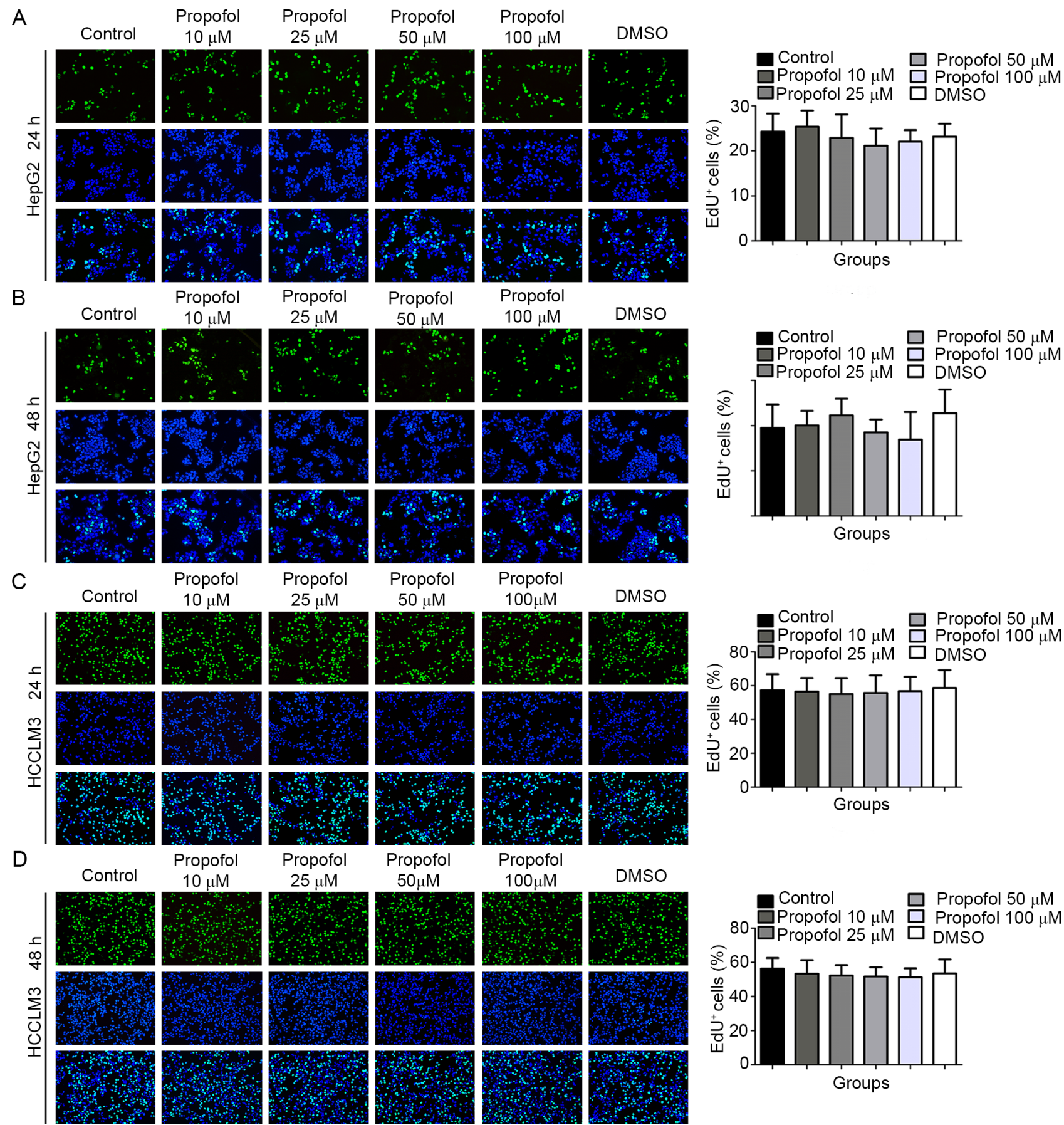

Figure 2. Effect of propofol on the proliferation of (A and B) HepG2 and (C and D) HCCLM3 cells under normoxia. Left panel, representative images (magnification, x200); right panel, statistical analysis of each group. EdU, 5-ethynyl-2'-deoxyuridine.

propofol stimulation (control, 1.00 $\pm 0.00 ;$ DMSO, 0.94 \pm 0.03 $10 \mu \mathrm{M}$ propofol, $0.92 \pm 0.08 ; 25 \mu \mathrm{M}$ propofol, $0.95 \pm 0.09 ; 50 \mu \mathrm{M}$ propofol, $0.90 \pm 0.11 ; 100 \mu \mathrm{M}$ propofol, $0.92 \pm 0.15$; Fig. 1D). In addition, no statistically significant differences in cell viability were observed between the DMSO and control groups. The above results suggested that propofol exerted no effect on the viability of HepG2 and HCCLM3 cells under normoxic conditions.

Propofol exerts no effect on the proliferation of HepG2 and HCCLM3 cells under normoxia. The results of the EdU assay demonstrated that, compared with the control $(24.26 \pm 4.01)$ and DMSO (23.17 \pm 2.84$)$ groups, the percentage of EdU HepG2 cells following $10(25.37 \pm 3.56), 25(22.87 \pm 5.19)$, $50(21.15 \pm 3.82)$ or $100 \mu \mathrm{M}(22.05 \pm 2.54)$ propofol stimulation for $24 \mathrm{~h}$ was not statistically significantly different (Fig. 2A). Similar trends were observed in HepG2 cells following $48 \mathrm{~h}$ of propofol stimulation (control, 19.48 \pm 5.21 ; DMSO, 22.75 \pm 5.22 ;

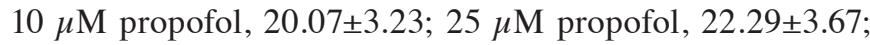
$50 \mu \mathrm{M}$ propofol $18.52 \pm 2.85 ; 100 \mu \mathrm{M}$ propofol, 16.91 \pm 6.13 ; Fig. 2B), in HCCLM3 cells following $24 \mathrm{~h}$ of propofol stimulation (control, 57.31 \pm 9.45 ; DMSO, 58.69 $\pm 10.54 ; 10 \mu \mathrm{M}$

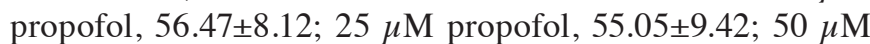
propofol, 55.72 $\pm 10.38 ; 100 \mu \mathrm{M}$ propofol, 56.77 \pm 8.49 ; Fig. $2 \mathrm{C}$ ) 
$\mathbf{A}$

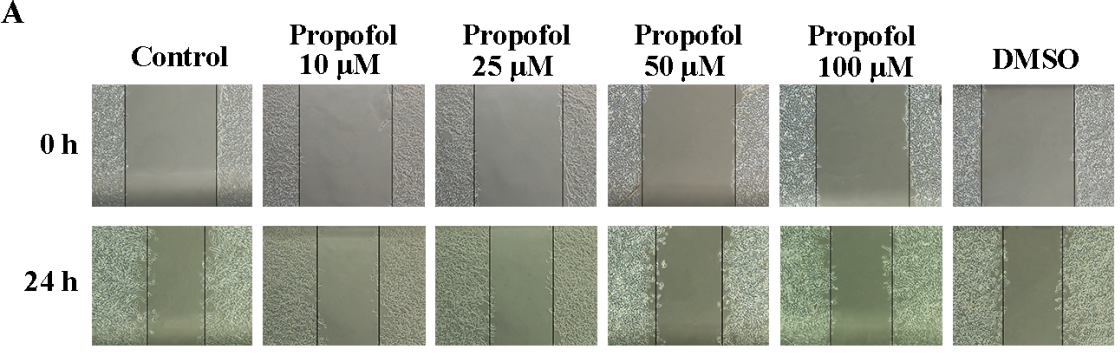

C

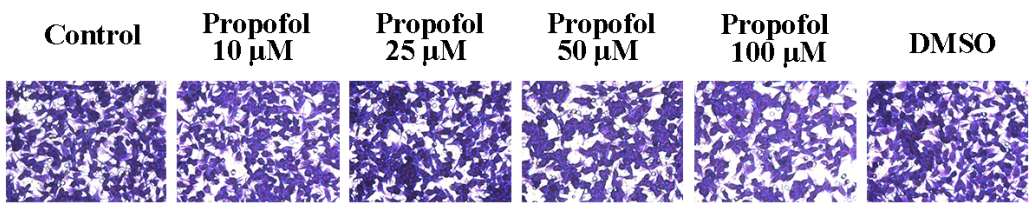

B

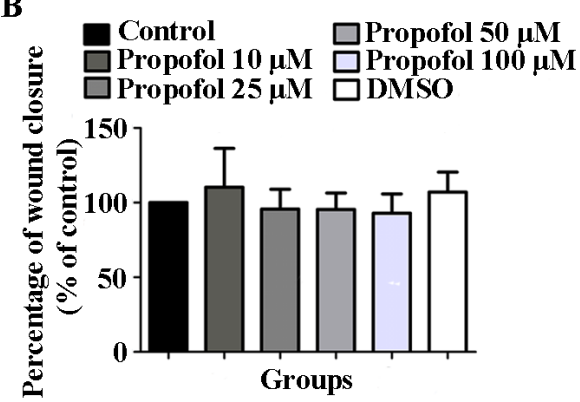

D

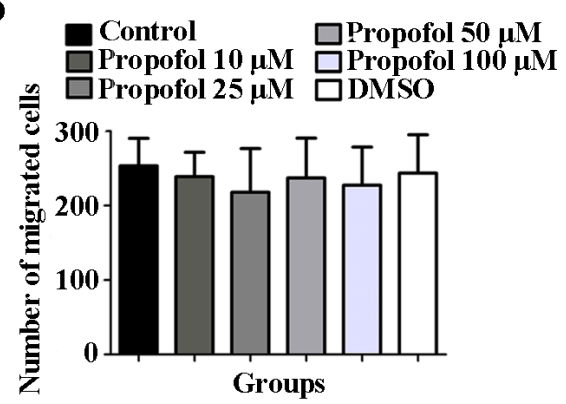

Figure 3. Effect of propofol on the migration of HCCLM3 cells under normoxia. (A) Representative images of the wound healing assay (magnification, x100). (B) Statistical analysis of part (A). (C) Representative images of the Transwell migration assay (magnification, x400). (D) Statistical analysis of part (C).

and in HCCLM3 cells following $48 \mathrm{~h}$ of propofol stimulation (control, 56.30 $\pm 6.29 ;$ DMSO, 53.51 $\pm 8.21 ; 10 \mu \mathrm{M}$ propofol, $53.31 \pm 7.98 ; 25 \mu \mathrm{M}$ propofol, 52.26 $\pm 6.11 ; 50 \mu \mathrm{M}$ propofol, $51.69 \pm 5.45 ; 100 \mu \mathrm{M}$ propofol, 51.25 \pm 5.25 ; Fig. 2D). The above results indicated that propofol exerted no effect on the proliferation of HepG 2 and HCCLM3 cells under normoxic conditions.

Propofol exerts no effect on the migration of HCCLM3 cells under normoxia. The results of the wound healing and Transwell migration assays revealed that, compared with the control $(100.0 \pm 0.0)$ and DMSO (107.1 13.37$)$ groups, the wound closure percentage of HCCLM3 cells stimulated with 10 (110.4 \pm 25.97$), 25$ (95.68 \pm 13.30$), 50(95.49 \pm 10.91)$ or $100(92.92 \pm 12.83) \mu \mathrm{M}$ propofol for $24 \mathrm{~h}$ was not statistically significantly different (Fig. 3A and B). Similarly, the number of migratory HCCLM3 cells in the propofol groups [10 $(239.0 \pm 32.72), 25(217.8 \pm 58.77), 50(237.2 \pm 53.40)$ or 100 (227.5 \pm 51.11$) \mu \mathrm{M}$ ] following $48 \mathrm{~h}$ of stimulation was also not statistically significantly different compared with the control $(253.3 \pm 36.97)$ and DMSO (243.6 \pm 51.54$)$ groups (Fig. 3C and D). The results suggested that propofol exerted no effect on the migration of HCCLM3 cells under normoxic conditions.

Propofol exerts no effect on the viability and migration of HepG2 cells under $\mathrm{CoCl}_{2}$-induced hypoxia. The results of the western blotting analysis indicated that, compared with the control group, the protein levels of HIF-1 $\alpha$ in HepG2 cells treated with 200 and $300 \mu \mathrm{M} \mathrm{CoCl}_{2}$ for $24 \mathrm{~h}$ were significantly upregulated $(1.00 \pm 0.00$ vs. $1.80 \pm 0.60$ and $2.12 \pm 0.69$, respectively; $\mathrm{P}<0.001$; Fig. $4 \mathrm{~A}$ and $\mathrm{B})$. In addition, following the treatment of HepG2 cells with $200 \mu \mathrm{M} \mathrm{CoCl}_{2}$, the protein levels of HIF-1 $\alpha$ were upregulated at $4 \mathrm{~h}$ and reached a peak at $12 \mathrm{~h}(\mathrm{P}<0.05$ and $\mathrm{P}<0.01$, respectively; Fig. 4C and D), and were subsequently downregulated by $24 \mathrm{~h}$. Therefore, the 12 -h time point was selected for subsequent experiments. The effects of propofol on the viability and migration of $\mathrm{HepG} 2$ cells under $\mathrm{CoCl}_{2}$-induced hypoxia were further investigated. The results demonstrated

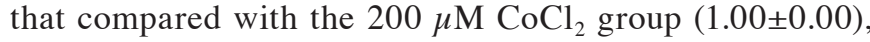
the viability of HepG2 cells following $12 \mathrm{~h}$ of stimulation with $10(1.07 \pm 0.21), 25(0.99 \pm 0.21), 50(1.01 \pm 0.16)$ or $100 \mu \mathrm{M}(0.99 \pm 0.24)$ propofol in the presence of $\mathrm{CoCl}_{2}$ was not significantly different (Fig. 4E). Similarly, the wound closure percentage in HepG2 cells following stimulation with $10(8.35 \pm 1.52), 25(8.55 \pm 1.94), 50(7.24 \pm 2.70)$ or 100 $(8.00 \pm 2.89) \mu \mathrm{M}$ propofol for $24 \mathrm{~h}$ in the presence of $\mathrm{CoCl}_{2}$ was also not statistically significantly different compared with the $200 \mu \mathrm{M} \mathrm{CoCl}_{2}$ group (7.79 \pm 2.01 ) (Fig. 4F and G). In HCCLM3 cells, pre-experimental results revealed that low concentrations of $\mathrm{CoCl}_{2}(\leq 150 \mu \mathrm{mol} / \mathrm{l})$ failed to induce an increase in $\mathrm{HIF}-1 \alpha$ protein levels. An increase in $\mathrm{CoCl}_{2}$ concentration $(>150 \mu \mathrm{mol} / \mathrm{l})$ resulted in morphological changes and the death of HCCLM3 cells (data not shown). The results suggested that the hypoxia model of HCCLM3 cells was not successfully induced by $\mathrm{CoCl}_{2}$ in this experiment. These above results indicated that propofol exerted no effect on the viability and migration of HepG2 cells under hypoxia induced by $\mathrm{CoCl}_{2}$.

\section{Discussion}

The main finding of the present study was that different concentrations of propofol $(10,25,50$ and $100 \mu \mathrm{M})$ had no effect on the viability, proliferation and migration of HepG2 and $\mathrm{HCCLM} 3$ cells in vitro under normoxic or $\mathrm{CoCl}_{2}$-induced hypoxic conditions. It has been demonstrated that anesthetics 
A

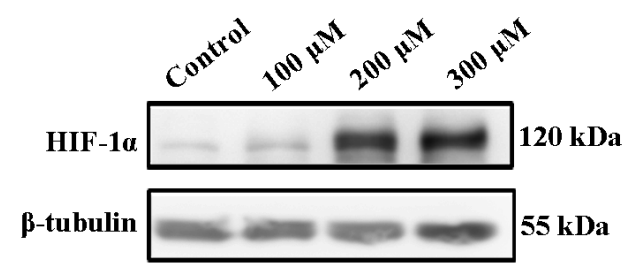

D

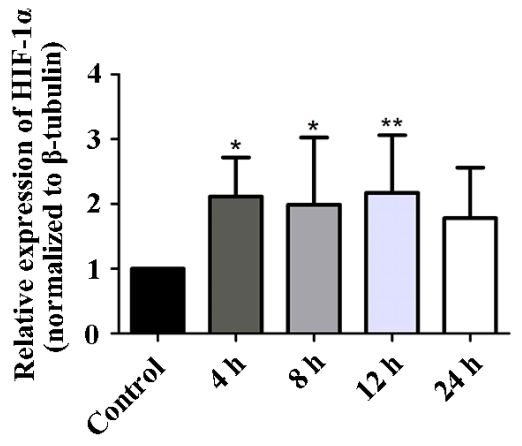

B

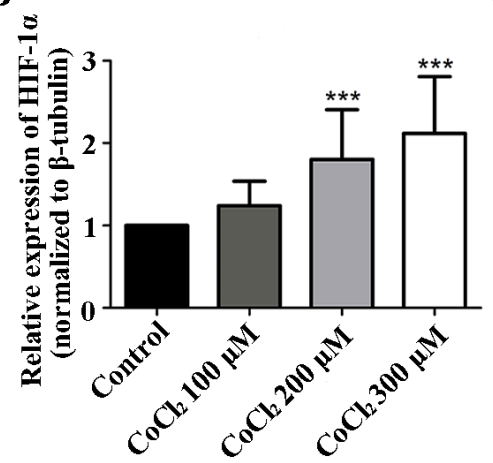

C

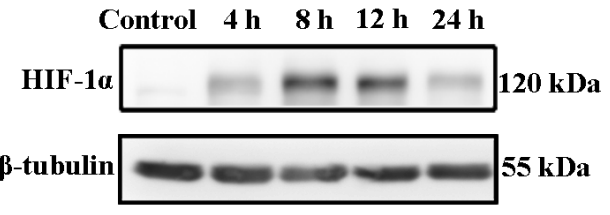

$\mathbf{F}$

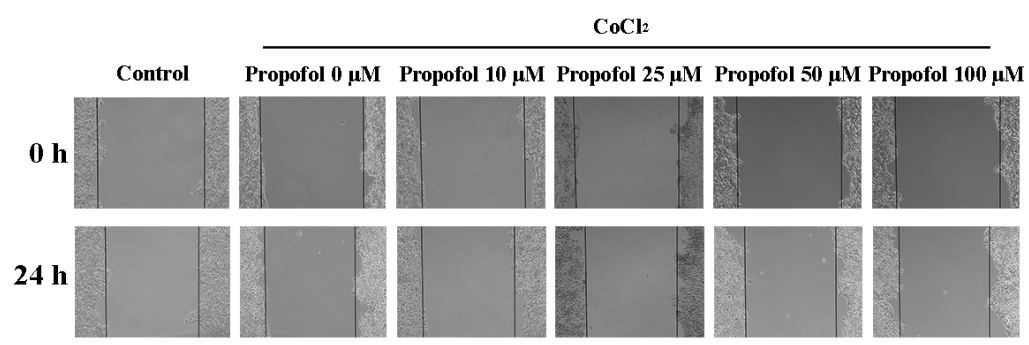

$\mathbf{E}$

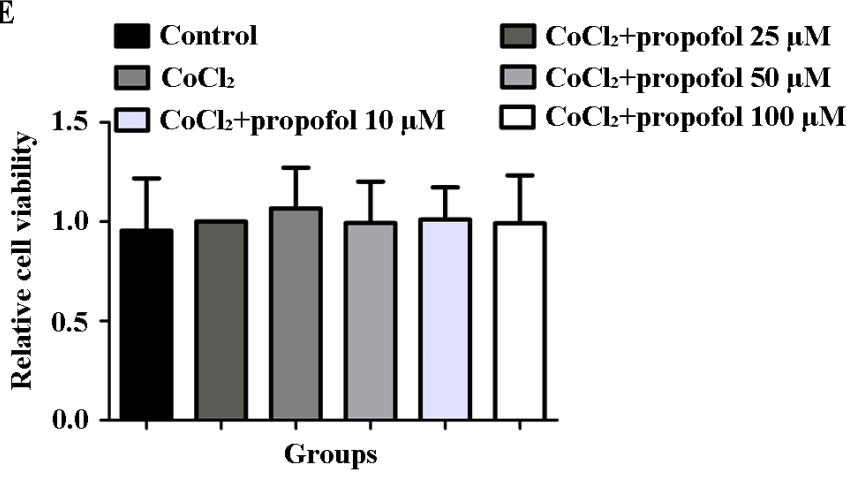

$\square \mathrm{CoCl}_{2}+$ propofol $25 \mu \mathrm{M}$ $\square \mathrm{CoCl}_{2}+$ propofol $50 \mu \mathrm{M}$ $\square \mathrm{CoCl}_{2}+$ propofol $100 \mu \mathrm{M}$

$\mathbf{G}$

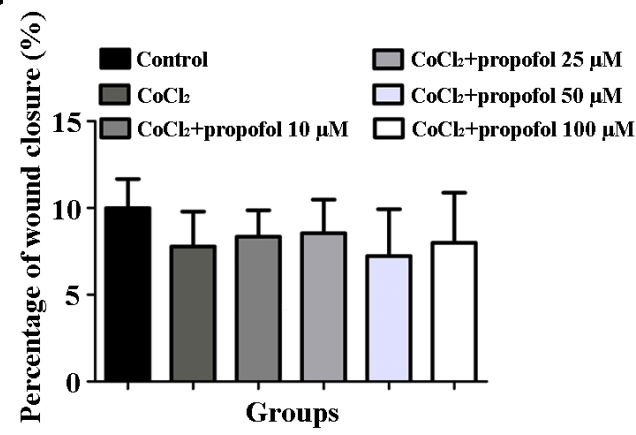

Figure 4. Effect of propofol on the viability and migration of $\mathrm{HepG} 2$ cells under $\mathrm{CoCl}_{2}$-induced hypoxia. $\mathrm{HepG} 2$ cells were treated with different concentra-

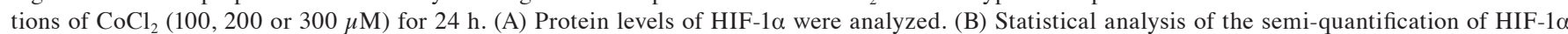
protein levels in part (A). HepG2 cells were treated with $200 \mu \mathrm{M} \mathrm{CoCl}_{2}$ for different durations (4, 8, 12 and $24 \mathrm{~h}$ ). (C) Protein levels of HIF-1 $\alpha$ were analyzed. (D) Statistical analysis of the semi-quantification of HIF-1 $\alpha$ protein levels in part (C). HepG2 cells were co-treated with $200 \mu \mathrm{M} \mathrm{CoCl}_{2}$ and propofol and (E) cell viability and (F) cell migration (magnification, $\mathrm{x} 100$ ) were determined. (G) Statistical analysis of part $(\mathrm{F}) .{ }^{*} \mathrm{P}<0.05,{ }^{* * *} \mathrm{P}<0.01,{ }^{* * * *} \mathrm{P}<0.001 \mathrm{vs}$. control group. $\mathrm{CoCl}_{2}$, cobalt chloride; HIF-1 $\alpha$, hypoxia inducible factor- $1 \alpha$.

may affect the long-term prognosis of patients with cancer who have a compromised immune response during major surgery with increased risk of regrowth and metastasis of their malignant tumors (31). Therefore, evaluating the effects of anesthetics on cancer cells could provide a basis for the appropriate use of anesthetics in patients with cancer in order to improve their prognosis. Propofol is one of the most common anesthetics used for both the induction and maintenance of anesthesia in cancer surgery (32), and, undoubtedly, numerous such cases are liver cancer surgery. To date, the effects of propofol on different types of cancer cell cultured in vitro remain contradictory $(16-18,24,25)$, and the mechanisms of action of propofol have not been clarified. Therefore, the present study aimed to investigate the effects of propofol on the proliferation and migration of liver cancer cells.
A previous study demonstrated that cancer cells are usually exposed to a hypoxic microenvironment in the body as a result of their rapid proliferation (26). Hypoxia can prompt tumors to metastasize to distant tissues rich in oxygen, thereby facilitating the development of tumor cells with highly aggressive phenotypes (33). One of the most important adaptive responses to hypoxia is the activation of HIF-1 $\alpha$, which can upregulate the expression levels of genes involved in cell proliferation, migration and angiogenesis, and promote the glucose metabolism of tumor cells to shift from oxidative phosphorylation to aerobic glycolysis to provide sufficient energy to meet the needs of rapid tumor proliferation (34). Hypoxia was previously reported to be associated with a poor prognosis in liver cancer (35). Therefore, the present study aimed to investigate the effects of propofol on liver cancer cells under $\mathrm{CoCl}_{2}$-induced hypoxic conditions. The results 
of the present study on the $\mathrm{CoCl}_{2}$-induced hypoxia model of HepG2 cells revealed that propofol stimulation had no effect on cell viability and migration.

A previous study found that in prostate cancer PC3 cells, propofol stimulation alone does not alter cell proliferation and migration (21), which is consistent with the findings of the current study. However, contrary to the present findings, numerous studies have demonstrated that propofol exerts significant advantages against liver cancer by decreasing cell proliferation and migration (36-38), while other studies showed that propofol stimulation promotes cancer cell proliferation and migration $(24,39)$. Several other studies have reported that propofol suppresses cell migration without affecting the levels of proliferation $(25,40)$. In contrast to these, Deegan et al (41) demonstrated that anesthesia with propofol reduces cell proliferation, but not migration. These aforementioned findings indicated that propofol may not serve an anticancer role in all types of neoplasms. The cell type, propofol concentration and duration of stimulation in the present study were consistent with those implemented in previous studies $(37,38)$. There are several possible explanations for the observed differences between the current results and previous findings. First, owing to the inter- and intratumor heterogeneity and the diversity of liver cancer cells (42), the sensitivity to propofol may vary in different liver cancer cells. Second, it is now widely accepted that tumor proliferation and metastasis are not independent events in tumor cells, as tumors are required to interact with their microenvironment (43). Therefore, changes in the microenvironment of liver cancer cells cultured in vitro may affect cell proliferation and migration. Third, propofol may act through a variety of factors such as microRNA (18), transforming growth factor- $\beta$ (44) and Nrf2 (39). Thus, changes in the expression levels of these factors may also account for the diverse responses of cancer cells to propofol.

There were also several limitations to the present study. For example, the effect of propofol on HIF-1 $\alpha$ protein levels in the $\mathrm{CoCl}_{2}$-induced hypoxia model were not investigated. In addition, the effects of propofol on the expression levels of proliferation- and migration-related genes were not determined. The study was also limited because it only included in vitro cell experiments, while investigating the effects of propofol in liver cancer model mice in vivo or using primary cell cultures from tissue specimens obtained from liver cancer model mice would produce more reliable results and help validate the present findings.

In conclusion, the results of the present study indicated that the anticancer effects of propofol may be questionable and controversial, and further investigations are required to determine the potential of propofol as a targeted anticancer drug. Although several studies have suggested that propofol-based anesthesia may have potential benefits for the survival of cancer patients $(45,46)$, to the best of our knowledge, there is currently no clear evidence to support the selection of propofol as the optimum choice of anesthesia for liver cancer surgery.

\section{Acknowledgements}

Not applicable.

\section{Funding}

This study was supported by The Zhejiang Provincial Public Welfare Technology Application Research Foundation of China (grant. no. 2018ZD033).

\section{Availability of data and materials}

The datasets used and/or analyzed during the current study are available from the corresponding author on reasonable request.

\section{Authors' contributions}

WS and CL contributed to the design of the study and project administration. CL, QF and JC performed the experiments and analyzed the data. HM performed the statistical analysis. CL interpreted the data. WS, CL and QF confirmed the authenticity of all raw data. CL and WS drafted, reviewed and edited the manuscript. All authors read and approved the final manuscript.

\section{Ethics approval and consent to participate}

Not applicable.

\section{Patient consent for publication}

Not applicable.

\section{Competing interests}

The authors declare that they have no competing interests.

\section{References}

1. Bray F, Ferlay J, Soerjomataram I, Siegel RL, Torre LA and Jemal A: Global cancer statistics 2018: GLOBOCAN estimates of incidence and mortality worldwide for 36 cancers in 185 countries. CA Cancer J Clin 68: 394-424, 2018.

2. Torre LA, Bray F, Siegel RL, Ferlay J, Lortet-Tieulent J and Jemal A: Global cancer statistics, 2012. CA Cancer J Clin 65: 87-108, 2015

3. Islami F, Miller KD, Siegel RL, Fedewa SA, Ward EM and Jemal A: Disparities in liver cancer occurrence in the United States by race/ethnicity and state. CA Cancer J Clin 67: 273-289, 2017.

4. Siegel RL, Miller KD and Jemal A: Cancer statistics, 2020. CA Cancer J Clin 70: 7-30, 2020.

5. Bruix J and Sherman M: Management of hepatocellular carcinoma: An update. Hepatology 53: 1020-1022, 2011

6. Xu XF, Xing H, Han J, Li ZL, Lau WY, Zhou YH, Gu WM, Wang H, Chen TH, Zeng YY, et al: Risk factors, patterns, and outcomes of late recurrence after liver resection for hepatocellular carcinoma: A multicenter study from China. JAMA Surg 154: 209-217, 2019.

7. Zhang H, Han J, Xing H, Li Z, Schwartz ME, Zhou Y, Chen T, Wang H, Gu W, Lau WY, et al: Sex difference in recurrence and survival after liver resection for hepatocellular carcinoma: A multicenter study. Surgery 165: 516-524, 2019.

8. Bruix J, Takayama T, Mazzaferro V, Chau G, Yang J, Kudo M, Cai J, Poon RT, Han K, Tak WY, et al: Adjuvant sorafenib for hepatocellular carcinoma after resection or ablation (STORM): A phase 3, randomised, double-blind, placebo-controlled trial. Lancet Oncol 16: 1344-1354, 2015 . 
9. Yeager MP and Rosenkranz KM: Cancer recurrence after surgery. Region Anesth Pain Med 35: 483-484, 2010.

10. Lee JW, Shahzad MMK, Lin YG, Armaiz-Pena G, Mangala LS, Han H, Kim H, Nam EJ, Jennings NB, Halder J, et al: Surgical stress promotes tumor growth in ovarian carcinoma. Clin Cancer Res 15: 2695-2702, 2009.

11. Wall T, Sherwin A, Ma D and Buggy DJ: Influence of perioperative anaesthetic and analgesic interventions on oncological outcomes: A narrative review. Br J Anaesth 123: 135-150, 2019.

12. Kim R: Effects of surgery and anesthetic choice on immunosuppression and cancer recurrence. J Transl Med 16: 8-13, 2018.

13. Vasileiou I, Xanthos T, Koudouna E, Perrea D, Klonaris C, Katsargyris A and Papadimitriou L: Propofol: A review of its non-anaesthetic effects. Eur J Pharmacol 605: 1-8, 2009.

14. Irwin MG, Chung CKE, Ip KY and Wiles MD: Influence of propofol-based total intravenous anaesthesia on peri-operative outcome measures: A narrative review. Anaesthesia 75: e90-e100, 2020 .

15. Zhang J, Shan WF, Jin TT, Wu GQ, Xiong XX, Jin HY and Zhu SM: Propofol exerts anti-hepatocellular carcinoma by microvesicle-mediated transfer of miR-142-3p from macrophage to cancer cells. J Transl Med 12: 279, 2014.

16. Zheng $\mathrm{H}, \mathrm{Fu} \mathrm{Y}$ and Yang T: Propofol inhibits proliferation, migration, and invasion of hepatocellular carcinoma cells by downregulating Twist. J Cell Biochem 120: 12803-12809, 2019.

17. Liu W and Liu N: Propofol inhibits lung cancer A549 cell growth and epithelial-mesenchymal transition process by upregulation of microRNA-1284. Oncol Res 27: 1-8, 2018.

18. Du Q, Zhang X, Zhang X, Wei M, Xu H and Wang S: Propofol inhibits proliferation and epithelial-mesenchymal transition of MCF-7 cells by suppressing miR-21 expression. Artif Cells Nanomed Biotechnol 47: 1265-1271, 2019.

19. Zhang YF, Li CS, Zhou Y and Lu XH: Effects of propofol on colon cancer metastasis through STAT3/HOTAIR axis by activating WIF-1 and suppressing Wnt pathway. Cancer Med 9: $1842-1854,2020$

20. Zhu F, Li Q, Yang Y, Wang L and Wang J: Propofol suppresses proliferation, migration, invasion and promotes apoptosis by upregulating microRNA-140-5p in gastric cancer cells. Onco Targets Ther 12: 10129-10138, 2019.

21. Huang H, Benzonana LL, Zhao H, Watts HR, Perry NJ, Bevan C, Brown R and Ma D: Prostate cancer cell malignancy via modulation of HIF-1 $\alpha$ pathway with isoflurane and propofol alone and in combination. Br J Cancer 111: 1338-1349, 2014.

22. Gao Y, Yu X, Zhang F and Dai J: Propofol inhibits pancreatic cancer progress under hypoxia via ADAM8. J Hepatobiliary Pancreat Sci 26: 219-226, 2019.

23. Kushida A, Inada T and Shingu K: Enhancement of antitumor immunity after propofol treatment in mice. Immunopharm Immunot 29: 477-486, 2008.

24. Zhang L, Wang N, Zhou S, Ye W, Jing G and Zhang M: Propofol induces proliferation and invasion of gallbladder cancer cells through activation of Nrf2. J Exp Clin Cancer Res 31: 66, 2012.

25. Ecimovic P, Murray D, Doran P and Buggy DJ: Propofol and bupivacaine in breast cancer cell function in vitro-role of the NET1 gene. Anticancer Res 34: 1321-1331, 2014.

26. Masoud GN and Li W: HIF-1 $\alpha$ pathway: Role, regulation and intervention for cancer therapy. Acta Pharm Sin B 5: 378-389, 2015.

27. Tang B, Zhao F, Qu Y and Mu D: Hypoxia-inducible factor-1alpha: A promising target for tumor therapy. Ai Zheng 28: 775-782, 2009.

28. Muñoz Sánchez J and Chánez Cárdenas ME: The use of cobalt chloride as a chemical hypoxia model. J Appl Toxicol 39: 556-570, 2018

29. Albanese J, Martin C, Lacarelle B, Saux P, Durand A and Gouin F: Pharmacokinetics of long-term propofol infusion used for sedation in ICU patients. Anesthesiology 73: 214-217, 1990
30. Coetzee JF, Glen JB, Wium CA and Boshoff L: Pharmacokinetic model selection for target-controlled infusions of propofol. Assessment of three parameter sets. Anesthesiology 82: $1328-1345,1995$

31. Kim R: Anesthetic technique and cancer recurrence in oncologic surgery: Unraveling the puzzle. Cancer Metastasis Rev 36 159-177, 2017.

32. Yang C, Gao J, Yan N, Wu B, Ren Y, Li H and Liang J: Propofol inhibits the growth and survival of gastric cancer cells in vitro through the upregulation of ING3. Oncol Rep 37: 587-593, 2017.

33. Brahimi-Horn MC, Bellot G and Pouysségur J: Hypoxia and energetic tumour metabolism. Curr Opin Genet Dev 21: 67-72, 2011.

34. Wilson GK, Tennant DA and McKeating JA: Hypoxia inducible factors in liver disease and hepatocellular carcinoma: Current understanding and future directions. J Hepatol 61: 1397-1406, 2014.

35. Liu Y, Yan W, Tohme S, Chen M, Fu Y, Tian D, Lotze M, Tang D and Tsung A: Hypoxia induced HMGB1 and mitochondrial DNA interactions mediate tumor growth in hepatocellular carcinoma through Toll-like receptor 9. J Hepatol 63: 114-121, 2015.

36. Ou W, Lv J, Zou X, Yao Y, Wu J, Yang J, Wang Z and Ma Y: Propofol inhibits hepatocellular carcinoma growth and invasion through the HMGA2-mediated $\mathrm{Wnt} / \beta$-catenin pathway. Exp Ther Med 13: 2501-2506, 2017.

37. Gong T, Ning X, Deng Z, Liu M, Zhou B, Chen X, Huang S, $\mathrm{Xu}$ Y, Chen Z and Luo R: Propofol-induced miR-219-5p inhibits growth and invasion of hepatocellular carcinoma through suppression of GPC3-mediated Wnt/ $\beta$-catenin signalling activation. J Cell Biochem 120: 16934-16945, 2019.

38. Sun Y and Sun H: Propofol exerts anticancer activity on hepatocellular carcinoma cells by raising lncRNA DGCR5. J Cell Physiol 235: 2963-2972, 2019.

39. Meng C, Song L, Wang J, Li D, Liu Y and Cui X: Propofol induces proliferation partially via downregulation of $\mathrm{p} 53$ protein and promotes migration via activation of the Nrf2 pathway in human breast cancer cell line MDA-MB-231. Oncol Rep 37: 841-848, 2017.

40. Li R, Huang Y and Lin J: Distinct effects of general anesthetics on lung metastasis mediated by IL-6/JAK/STAT3 pathway in mouse models. Nat Commun 11: 642, 2020

41. Deegan CA, Murray D, Doran P, Ecimovic P, Moriarty DC and Buggy DJ: Effect of anaesthetic technique on oestrogen receptor-negative breast cancer cell function in vitro. Brit J Anaesth 103: 685-690, 2009.

42. Da Silva-Diz V, Lorenzo-Sanz L, Bernat-Peguera A, Lopez-Cerda M and Muñoz P: Cancer cell plasticity: Impact on tumor progression and therapy response. Semin Cancer Biol 53: 48-58, 2018

43. Guan X: Cancer metastases: Challenges and opportunities. Acta Pharm Sin B 5: 402-418, 2015.

44. Xu YB, Jiang W, Zhao FR, Li G, Du QH, Zhang MY and Guo XG: Propofol suppresses invasion and induces apoptosis of osteosarcoma cell in vitro via downregulation of TGF- $\beta 1$ expression. Eur Rev Med Pharmacol Sci 20: 1430-1435, 2016.

45. Wigmore TJ, Mohammed K and Jhanji S: Long-term survival for patients undergoing volatile versus IV anesthesia for cancer surgery: A retrospective analysis. Anesthesiology 124: 69-79, 2016.

46. Wu ZF, Lee MS, Wong CS, Lu CH, Huang YS, Lin KT, Lou YS, Lin C, Chang YC and Lai HC: Propofol-based total intravenous anesthesia is associated with better survival than desflurane anesthesia in colon cancer surgery. Anesthesiology 129: 932-941, 2018.

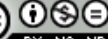

This work is licensed under a Creative Commons Attribution-NonCommercial-NoDerivatives 4.0 International (CC BY-NC-ND 4.0) License. 